\title{
Performance and Emission Characteristics of Diesel Engine Fueled with Ethanol-Diesel Blends in Different Altitude Regions
}

\author{
Jilin Lei, Yuhua Bi, and Lizhong Shen \\ Faculty of Transportation Engineering, Kunming University of Science and Technology, Kunming 650224, China \\ Correspondence should be addressed to Lizhong Shen, lzshen@public.km.yn.cn
}

Received 11 June 2010; Revised 5 October 2010; Accepted 8 November 2010

Academic Editor: Andrei Surguchov

Copyright () 2011 Jilin Lei et al. This is an open access article distributed under the Creative Commons Attribution License, which permits unrestricted use, distribution, and reproduction in any medium, provided the original work is properly cited.

In order to investigate the effects ethanol-diesel blends and altitude on the performance and emissions of diesel engine, the comparative experiments were carried out on the bench of turbo-charged diesel engine fueled with pure diesel (as prototype) and ethanol-diesel blends (E10, E15, E20 and E30) under different atmospheric pressures (81 kPa, $90 \mathrm{kPa}$ and $100 \mathrm{kPa})$. The experimental results indicate that the equivalent brake-specific fuel consumption (BSFC) of ethanol-diesel blends are better than that of diesel under different atmospheric pressures and that the equivalent BSFC gets great improvement with the rise of atmospheric pressure when the atmospheric pressure is lower than $90 \mathrm{kPa}$. At $81 \mathrm{kPa}$, both $\mathrm{HC}$ and CO emissions rise greatly with the increasing engine speeds and loads and addition of ethanol, while at $90 \mathrm{kPa}$ and $100 \mathrm{kPa}$ their effects on $\mathrm{HC}$ and CO emissions are slightest. The changes of atmospheric pressure and mix proportion of ethanol have no obvious effect on $\mathrm{NO}_{x}$ emissions. Smoke emissions decrease obviously with the increasing percentage of ethanol in blends, especially atmospheric pressure below $90 \mathrm{kPa}$.

\section{Introduction}

Recently, diesel engine has received considerable attention because of its high heat efficiency and low emission; however, with the stringent emission standard and limited petroleum reserve, alternative fuels for diesel engine have been used. As a renewable and oxygen-containing biofuel, ethanol is a prospective fuel for vehicle, which can be blended with diesel or be injected into cylinder directly. There are many studies on the application of ethanol on diesel engine, which focus on the three aspects: application techniques of ethanol on diesel engine, fuel properties of ethanol-diesel blends, and effects on the combustion and emission characteristics of ethanol-diesel blends [1-6].

Because ethanol is polar molecule and its solubility in diesel is prone to be affected by temperature and water content, high percentage addition of ethanol to diesel is difficult, especially under low temperature (below about $10^{\circ} \mathrm{C}$ ). In order to mix ethanol and diesel, an emulsifier or cosolvent should be added. Many literatures indicated that aromatic hydrocarbon, middle distillate, and wax content of diesel are important factors of its blend with ethanol $[1,2]$. Presently, the application techniques of ethanol on diesel engine can be divided into the following four classes: (1) ethanol-diesel blend by high-pressure pump [3], (2) ethanol fumigation to the intake air charge by using carburetion or manifold injection, which is associated with limits to the amount of ethanol due to the incipience of engine knock at high loads, and prevention of flame quenching and misfire at low loads [3-6], (3) dual injection system requiring an extra high-pressure injection system and a related major design change of the cylinder head $[6,7]$, and (4) blends of ethanol and diesel fuel by using an emulsifier or cosolvent to mix the two fuels for preventing their separation, requiring no technical modifications on the engine side $[6,8,9]$.

The physical and chemical characteristics of ethanoldiesel blends are very important to its application on diesel engine. The stability, density, viscosity, surface tension, specific heat, heat value, and cetane number of blends have great impact on the injection, atomization, ignition, and combustion properties, as well as cold start, power, fuel consumption, and emission characteristics of engine. Additionally, the poking and leakage of conventional tank, fuel pipe, and sealing part can be rendered. More stringent demands are necessary for the mixture, transportation, 
storage, and usage of fuel because of low flash point of ethanol-diesel blends [9-13].

The cetane number is an important fuel property for diesel engines. It has an influence on engine start ability, emissions, peak cylinder pressure, and combustion noise. According to research carried out by Li et al. [12], each $10-$ vol\% ethanol added to the diesel fuel, results in a 7.1-unit reduction in cetane number of the resulting blend. References $[8,14,15]$ indicated that the addition of ethanol resulted in increased ignition delay, reduced combustion duration, high maximum pressure rates, and slightly decreased gas temperature because of its low cetane number and high/low heat value. With the addition of cetane number improver, the combustion properties can reach the level of prototype at middle-high load.

Without modification, the ethanol-diesel blends decreased the power of diesel engine and increased the brake-specific fuel consumption; however, the performance of prototype can be rehabilitated after adjusting the fuel delivery and injection timing of engine [16-18]. Reference [19] showed no significant power reduction in the engine operation on different blends of ethanol-diesel (up to 20\%) at a $5 \%$ level of significance. Brake-specific fuel consumption increased by up to $9 \%$ as compared to diesel alone. The exhaust gas temperature and lubricating oil temperatures were lower with operations on ethanol-diesel blends as compared to operation on diesel.

Ethanol-diesel blends can reduce the smoke and PM emissions of diesel engine. The higher this reduction is, the higher the percentage of ethanol is in the blends. The reason is that the oxygen content in blends can promote the combination of fuel and oxygen, even in fuel-rich region [16, 20-22]. The NOx emissions remained the same or very slightly reduced with the use of the ethanol-diesel fuel blends with respect to those of the diesel; however, the NOx emissions can be reduced by other techniques, such as EGR and SCR. The hydrocarbons (HCs) emissions were increased with the use of ethanol-diesel blends. The higher this increase is, the higher the percentage of ethanol in the blend, however, the HC emissions of blends can still meet the emission standards due to low $\mathrm{HC}$ emissions of diesel engine. References $[12,20]$ showed that the CO emissions of ethanoldiesel blends were increased at low load and were decreased at high load. Additionally, the $\mathrm{CO}_{2}$ emissions were decreased due to the low $\mathrm{C} / \mathrm{H}$ ratio of ethanol-diesel blends.

The irregular emissions of diesel engine were also affected by the addition of ethanol. Cheung et al. [23] reported that the unburned ethanol and acetaldehyde increased when a 4-cyclinder direct-injection diesel engine was fueled with ethanol-diesel blends, but formaldehyde, ethene, ethyne, 1,3-butadiene, and BTX (benzene, toluene, and xylene) in general decreased, especially at high engine load. A diesel oxidation catalyst (DOC) is found to reduce significantly most of the pollutants, including the air toxics. Song et al. [24] showed that the content of 16 kinds of PAHs and DNA damage level decreased in exhaust of E5 compare with that of diesel.

The atmospheric pressure and air density can affect the combustion process of engine, so the power performance,
TABLE 1: Engine Configuration.

\begin{tabular}{lc}
\hline Type & In-line, 4 cylinders \\
\hline Bore $\times$ stroke $(\mathrm{mm})$ & $100 \times 105$ \\
Displacement $(\mathrm{L})$ & 3.298 \\
Combustion chamber & $\omega$-type direct injection \\
Induction system & Turbocharged and intercooler \\
Compression ratio & $17.5: 1$ \\
Rated power $\left(\mathrm{kW} /\left(\mathrm{r} \cdot \mathrm{min}^{-1}\right)\right)$ & $73 / 3200$ \\
Maximum torque $\left(\mathrm{N} \cdot \mathrm{m} /\left(\mathrm{r} \cdot \mathrm{min}^{-1}\right)\right)$ & $245 / 2200$ \\
\hline
\end{tabular}

fuel consumption, and emission characteristics of engine will be different when the engine was run at different altitudes. So far, the application researches of ethanol-diesel blends were almost carried out at low altitude. Therefore, in order to investigate the effects of ethanol-diesel blends on the performance and emissions of diesel engine under different atmospheric pressures, the comparative experiments were done between the engine fueled with pure diesel (as prototype) and ethanol-diesel blends at different altitudes [25-27].

\section{Materials and Methods}

2.1. Test Engine. The test engine was a $3.298 \mathrm{~L}$, directinjection, turbocharged diesel engine. The relevant characteristic of detailed engine configuration was given in Table 1. During experiment the engine was tested without any modification.

\subsection{Emission Test Apparatus and the Realization of Different} Atmospheric Pressures. The emission test devices included an AC electric dynamometer (AVL AFA Drive 250/4-8), an exhaust analyzer (AVL CEB), a fuel consumption meter (AVL 733), and a smoke meter (AVL 415). The altitude of test bench is $1912 \mathrm{~m}$, and the local atmospheric pressure is $81 \mathrm{kPa}$. The relative humidity is $40 \sim 60 \%$, and temperature ranges from $18^{\circ} \mathrm{C}$ to $21^{\circ} \mathrm{C}$.

The different atmospheric pressures were produced by an engine condition system (AVL ACS1300/300), which can automatically controls the atmospheric pressures and inlet gas temperatures. The inlet of turbocharger compressor was connected to the pressure output of engine condition system, and the pressure sensor and temperature sensor were used. When the $c$ was $81 \mathrm{kPa}$, the exhaust back pressure was set at local environmental pressure. When the atmospheric pressure was $90 \mathrm{kPa}$ or $100 \mathrm{kPa}$, the back pressure of engine was adjusted to inlet pressure $[17,18]$.

2.3. Blend of Ethanol and Diesel. A hydraulic vibration emulsification device was developed, which was installed on the high-pressure pump of diesel engine. The ethanol and diesel were delivered to the emulsification device by two fuel delivery systems. The emulsified ethanol/diesel was injected into the cylinder by pump and injector. The emulsification device can provide different proportions of ethanol and diesel without modifying engine and stopping 


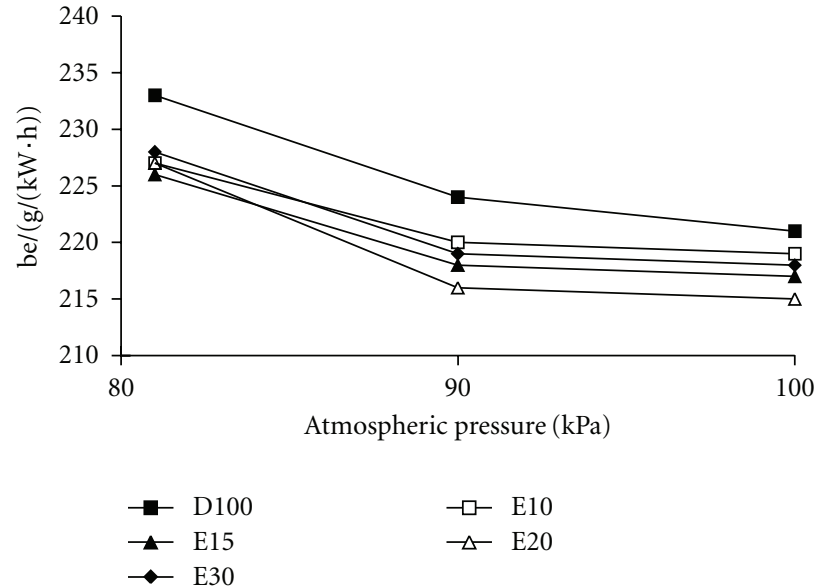

(a) $2200 \mathrm{r} / \mathrm{min} 230 \mathrm{~N} \cdot \mathrm{m}$

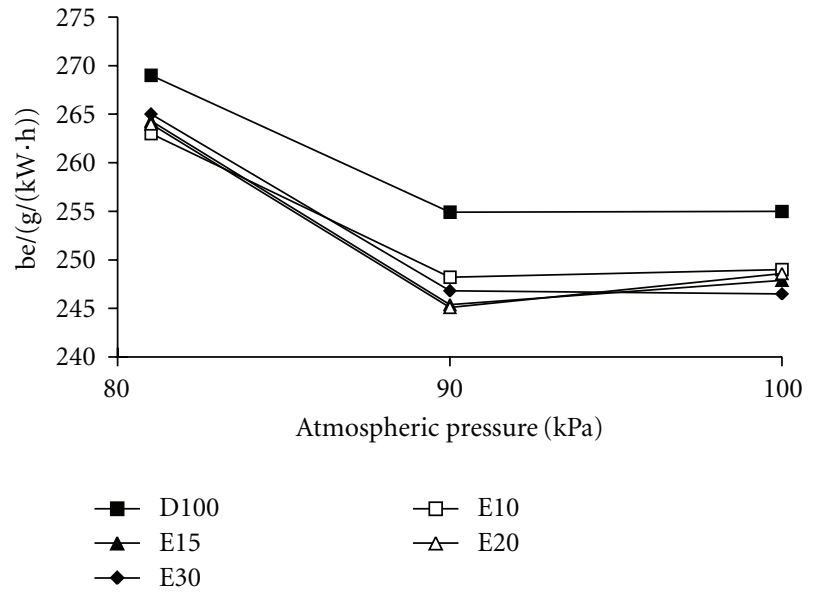

(b) $3200 \mathrm{r} / \mathrm{min} 190 \mathrm{~N} \cdot \mathrm{m}$

FIGURE 1: Effects of different atmospheric pressure and mix proportion on equivalent BSFC.

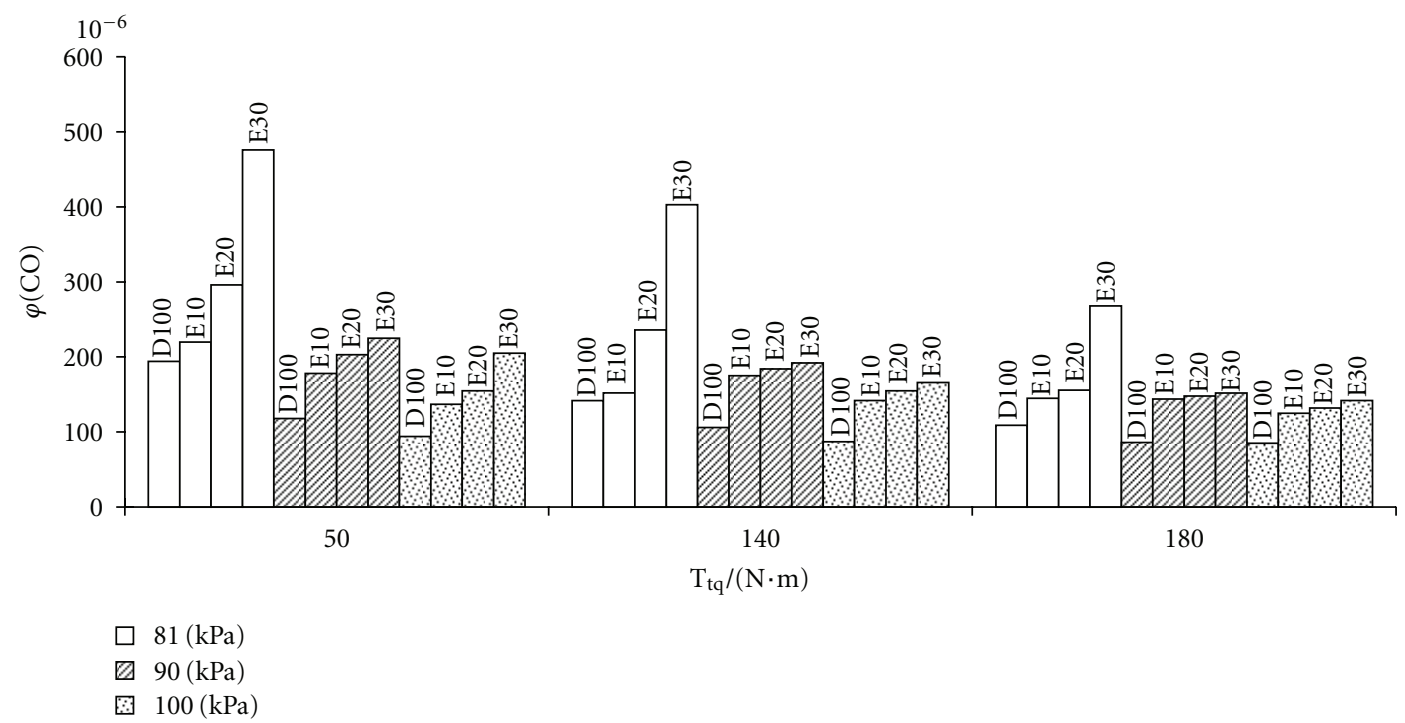

Figure 2: Comparison of HC emission of different atmospheric pressure and mix proportion at speed $1400 \mathrm{r} / \mathrm{min}$.

engine. The emulsification device can use the $95 \%$ ethanol without any emulsifier and surfactant. The test diesel is $0^{\#}$ diesel [5].

\section{Results and Discussions}

3.1. Analysis of Engine Performance. The low heat value (Qi) of ethanol is lower than that of diesel, so it is necessary to consider the effect of heat value when making comparison of brake-specific fuel consumption (BSFC) and then to refer to equivalent BSFC $\left(b_{\mathrm{e}}\right)$, defined as $b_{\mathrm{e}}=\mathrm{BSFC} * Q_{\mathrm{ie}} / Q_{\mathrm{id}}$. $Q_{\mathrm{ie}}$ and $Q_{\text {id }}$ are the low heat value of ethanol-diesel blends and diesel, respectively. Figure 1 illustrated the comparison of equivalent BSFC under three atmospheric pressures.

It can be seen that $b_{\mathrm{e}}$ of ethanol-diesel blends are lower than those of diesel. The ethanol is an oxygenated fuel with lower surface tension and boiling point, so the fast vaporization of ethanol can promote the spray performance and the formation of mixture gas, which is good for the premix and diffused combustion. Additionally, the higher oxygen content of ethanol can increase the excess air ratio and improve the heat efficiency. On the other hand, the decrease of $b_{e}$ was not proportioned to the addition of ethanol. Compared to diesel, E10 reduced $\mathrm{b}_{e}$ by $1.0 \sim 2.6 \%$, while E15 by $1.8 \sim 3.0 \%$, E20 by $2.6 \sim 2.7 \%$, and E30 by $1.4 \sim 2.1 \%$. The results indicated that E15 and E20 had better performance than E10 and E30 because E10 has lower proportion of ethanol and E30 maybe has bad emulsification.

It can be seen that $b_{\mathrm{e}}$ of both ethanol-diesel blends and diesel are decreased with the increase of atmospheric pressure. The reduction of $b_{\mathrm{e}}$ was great when atmospheric pressure changed from $81 \mathrm{kPa}$ to $90 \mathrm{kPa}$, while the reduction was slight when atmospheric pressure changed from $90 \mathrm{kPa}$ to $100 \mathrm{kPa}$. 


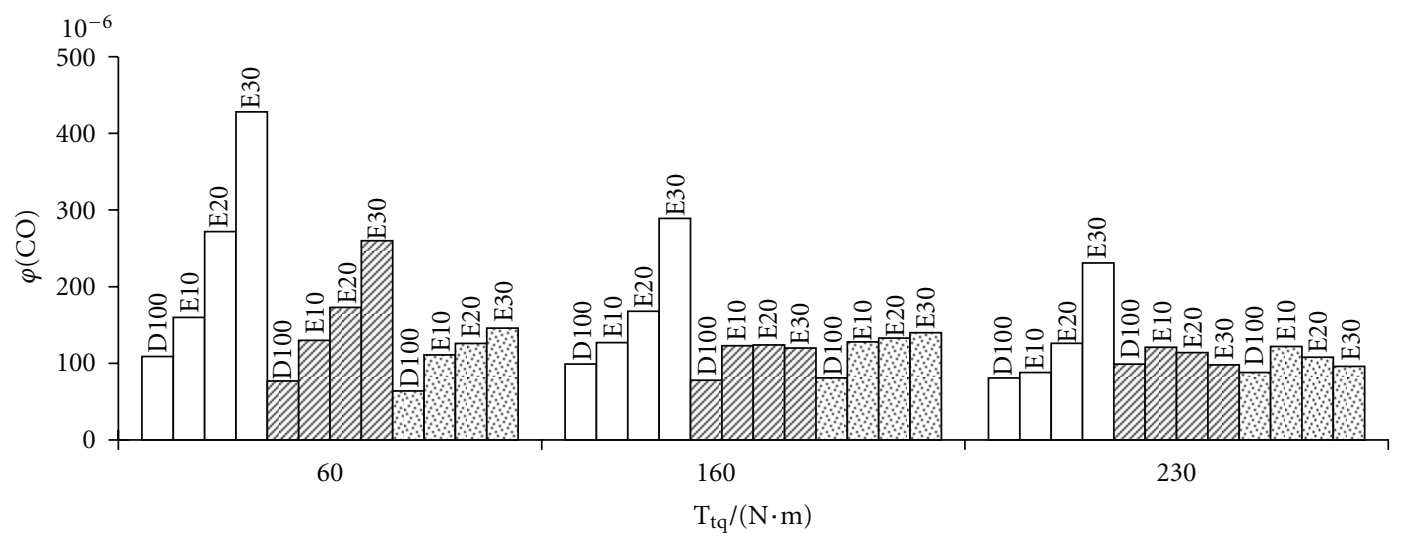
$\square 81(\mathrm{kPa})$
勿 $90(\mathrm{kPa})$
용 $100(\mathrm{kPa})$

FIGURE 3: Comparison of HC emission of different atmospheric pressure and mix proportion at speed $2200 \mathrm{r} / \mathrm{min}$.

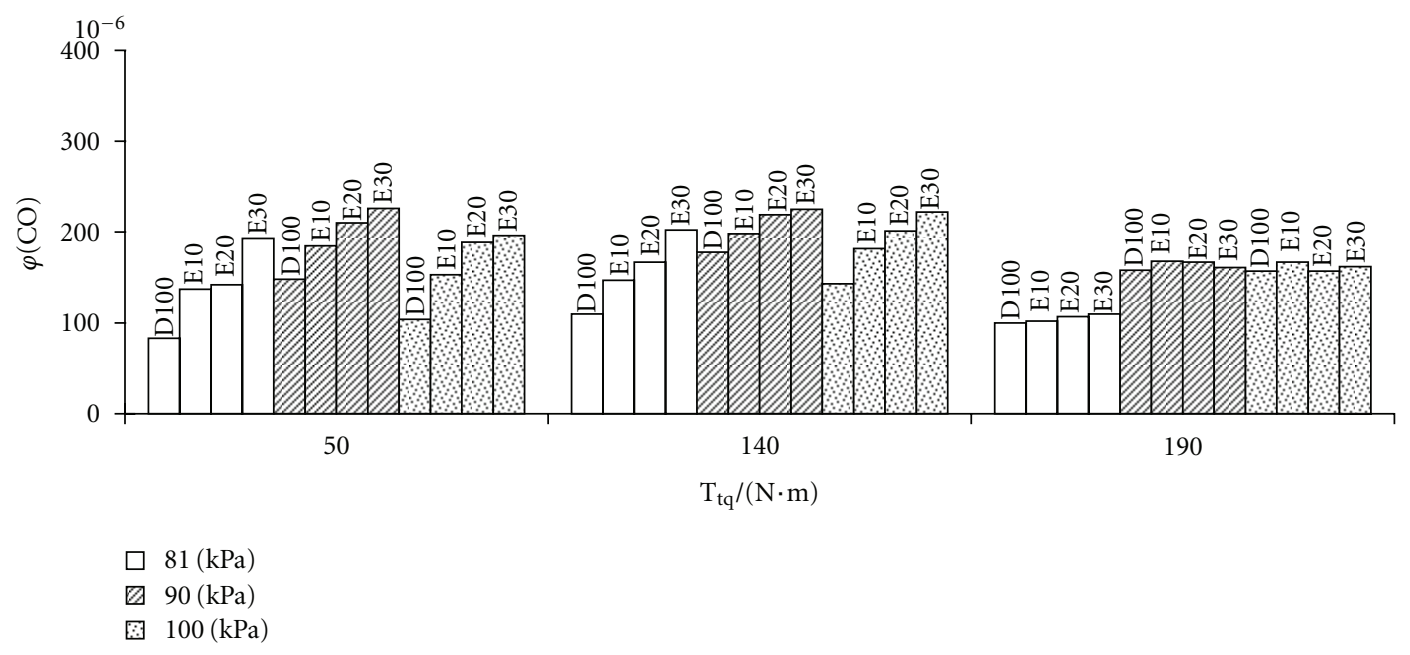

Figure 4: Comparison of HC emission of different atmospheric pressure and mix proportion at speed $3200 \mathrm{r} / \mathrm{min}$.

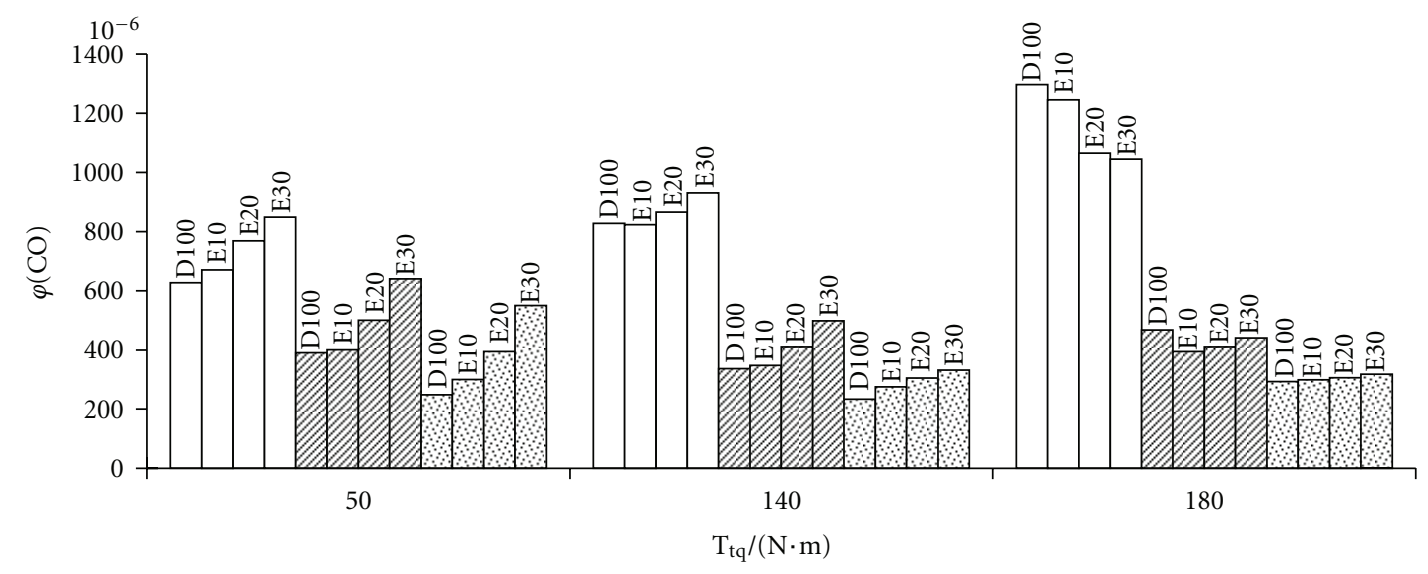
$\square 81(\mathrm{kPa})$
口 $90(\mathrm{kPa})$
용 $100(\mathrm{kPa})$

FIGURE 5: Comparison of CO emission of different atmospheric pressure and mix proportion at speed $1400 \mathrm{r} / \mathrm{min}$. 


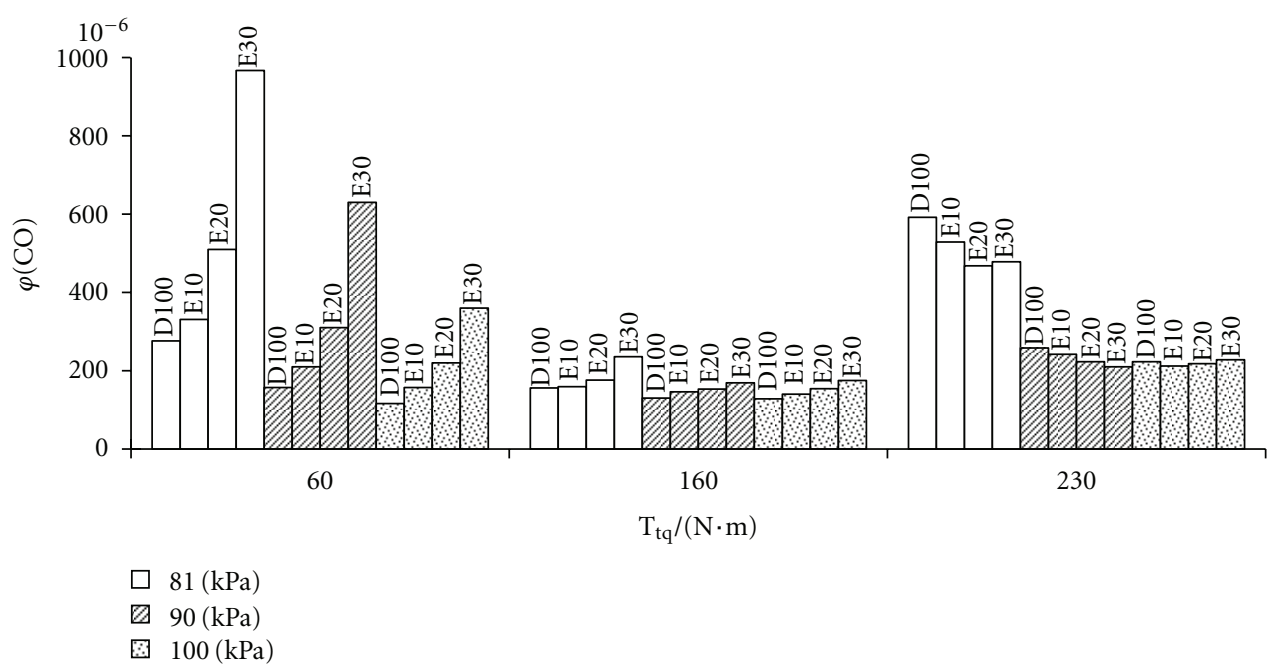

Figure 6: Comparison of CO emission of different atmospheric pressure and mix proportion at speed $2200 \mathrm{r} / \mathrm{min}$.

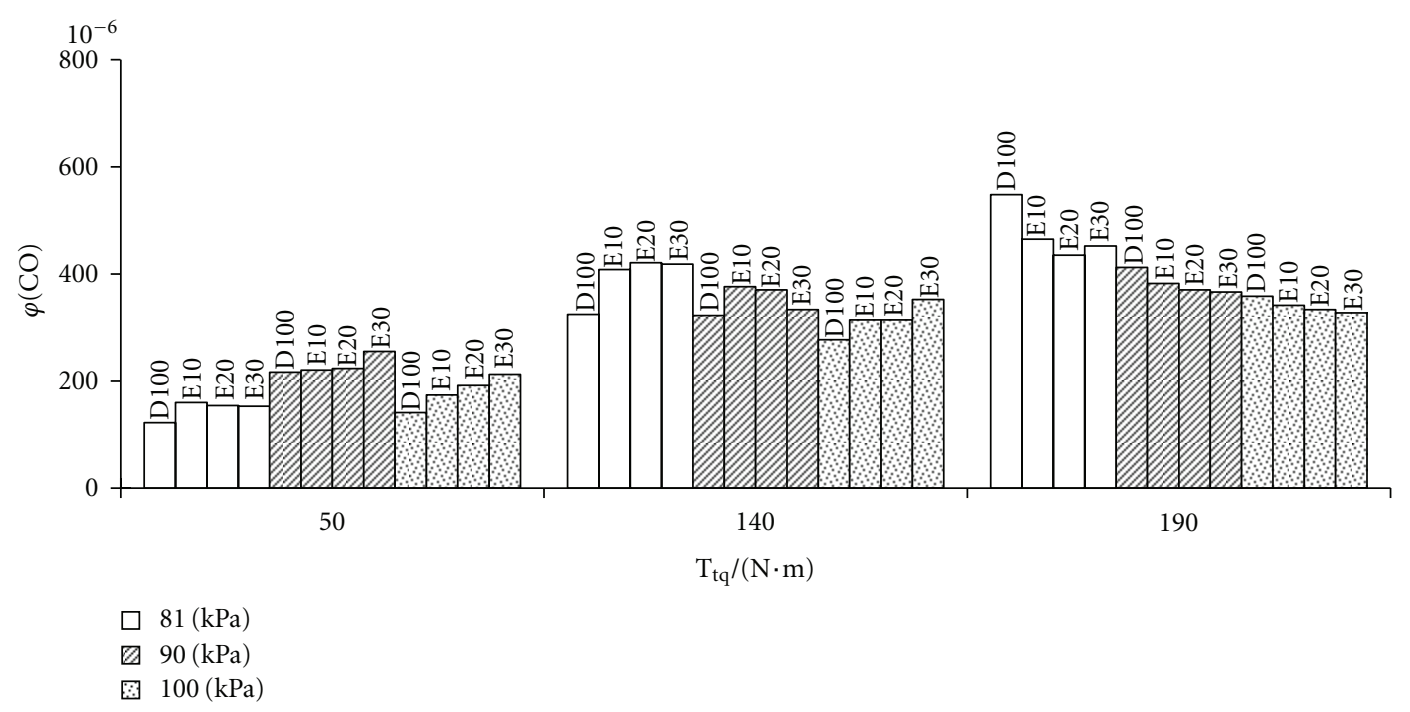

Figure 7: Comparison of CO emission of different atmospheric pressure and mix proportion at speed $3200 \mathrm{r} / \mathrm{min}$.

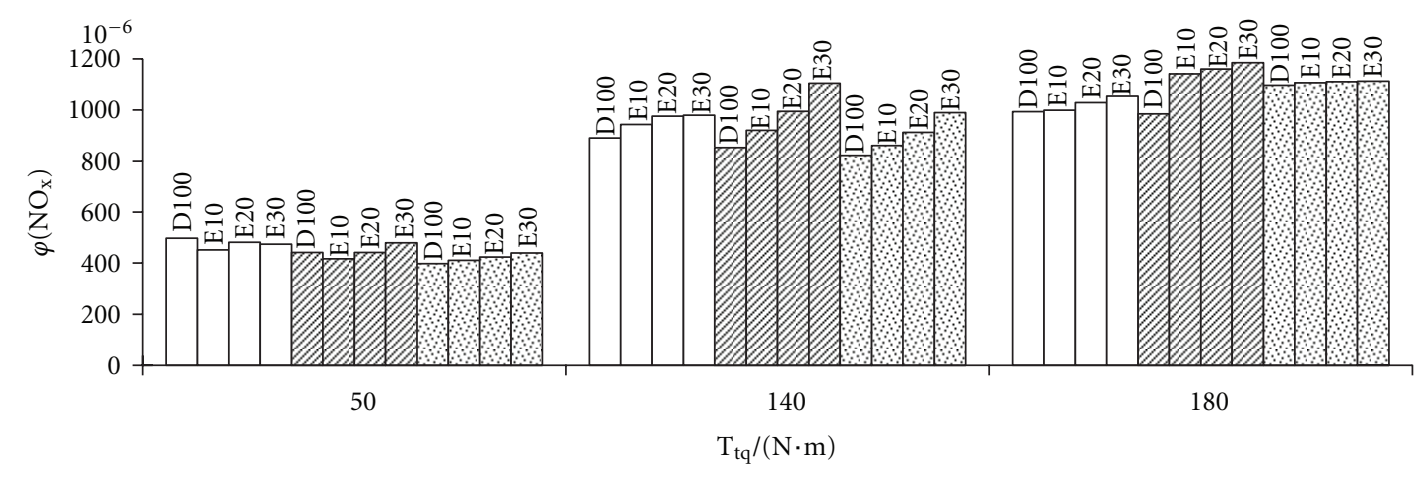

$$
\begin{aligned}
& \square 81(\mathrm{kPa}) \\
& \text { 임 } 90(\mathrm{kPa}) \\
& \text { 웅 } 100(\mathrm{kPa})
\end{aligned}
$$

Figure 8: Comparison of $\mathrm{NO}_{\mathrm{x}}$ emission of different atmospheric pressure and mix proportion at speed $1400 \mathrm{r} / \mathrm{min}$. 


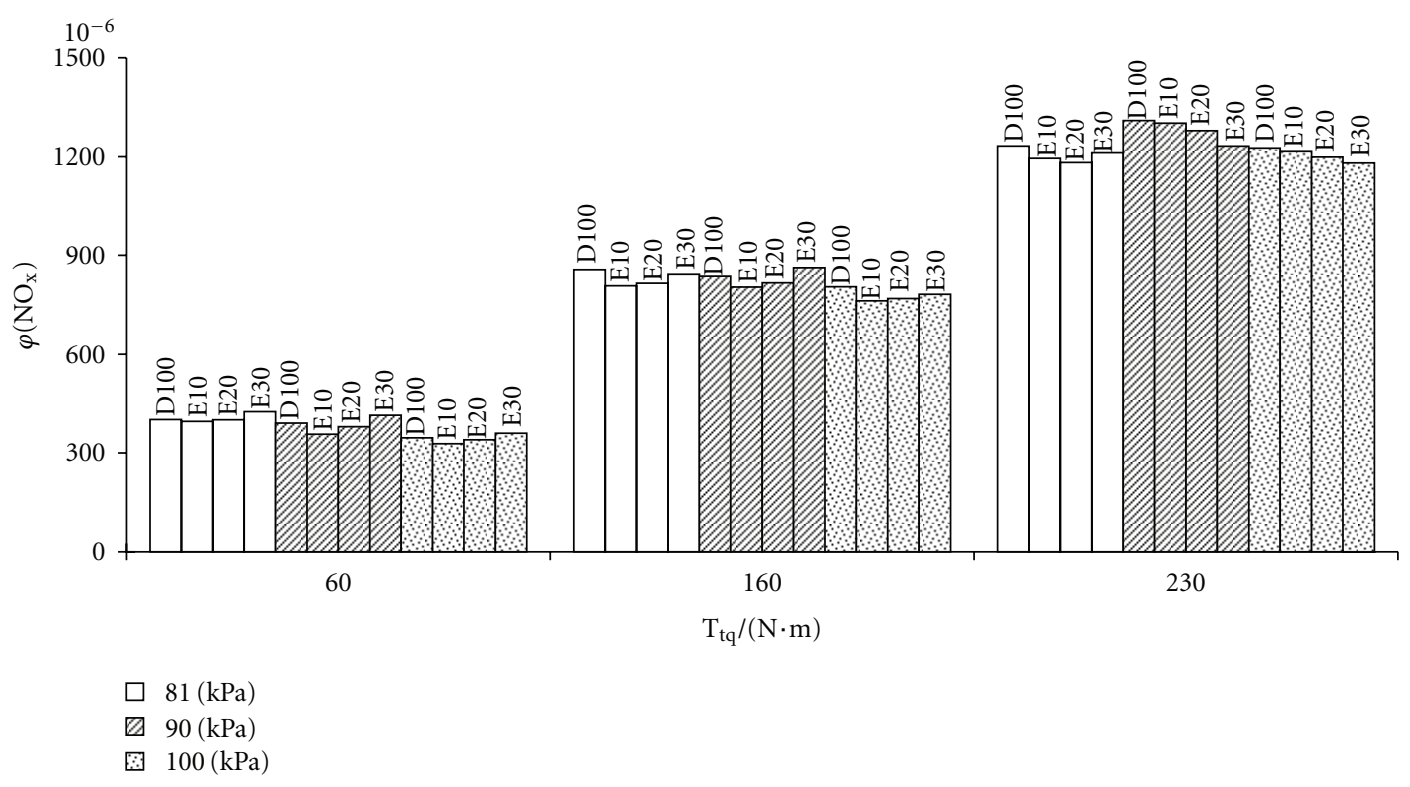

FIGURE 9: Comparison of $\mathrm{NO}_{\mathrm{x}}$ emission of different atmospheric pressure and mix proportion at speed $2200 \mathrm{r} / \mathrm{min}$.

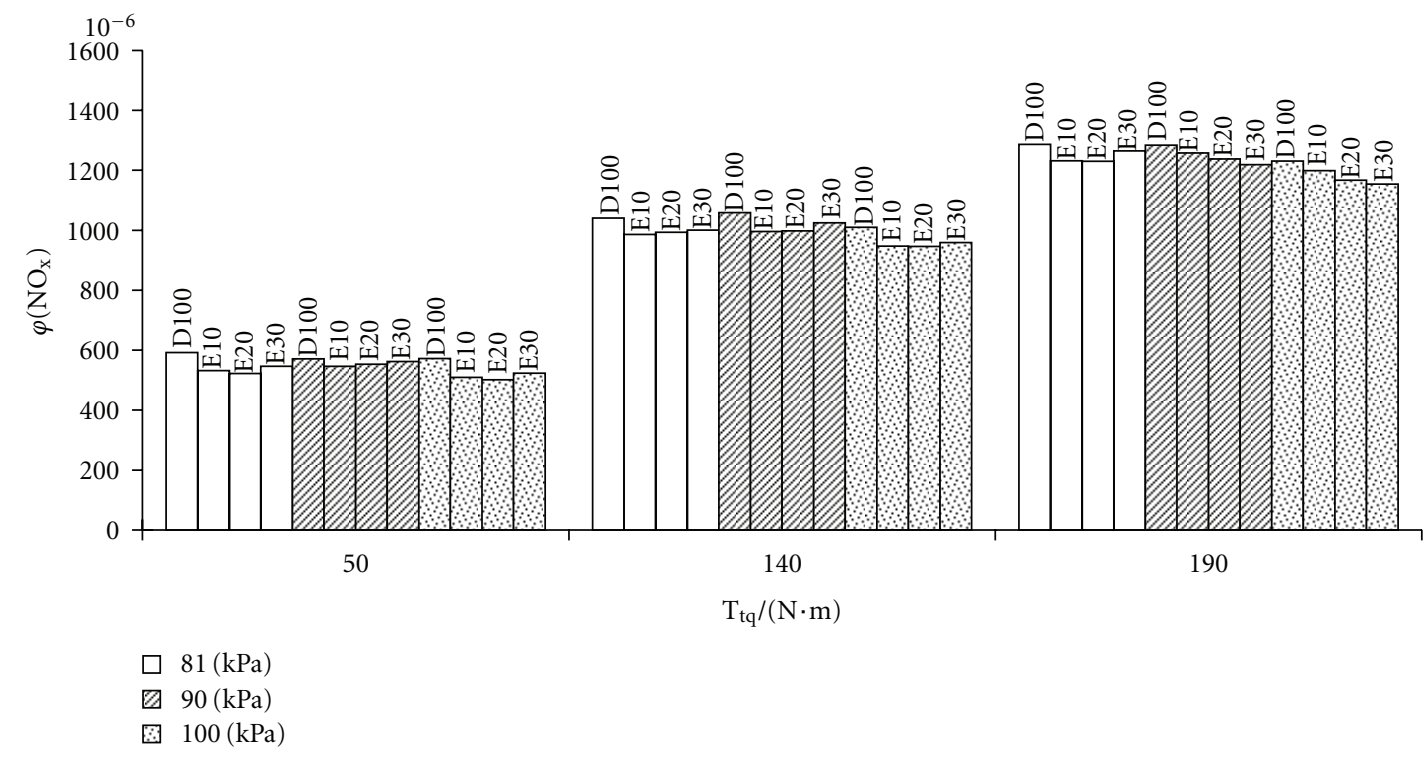

FIGURE 10: Comparison of $\mathrm{NO}_{\mathrm{x}}$ emission of different atmospheric pressure and mix proportion at speed $3200 \mathrm{r} / \mathrm{min}$.

3.2. Emission Characteristics of HC. The HC emissions of diesel-ethanol blends under three atmospheric pressures were shown in Figures 2, 3, and 4. It can be seen that the $\mathrm{HC}$ emissions under different atmospheric pressures show significant divergences when the mix proportions, engine speeds, and loads change. With increasing speeds and loads, the effect of atmospheric pressure on HC emission was not significant. At $2200 \mathrm{r} / \mathrm{min}$ and $81 \mathrm{kPa}$, the mix proportions had great effects on the $\mathrm{HC}$ emissions, especially at light load $(50 \mathrm{~N} \cdot \mathrm{m})$, which rendered the increase by $47 \% \sim 293 \%$. The increase of $\mathrm{HC}$ emissions of $\mathrm{E} 30$ was great. The $\mathrm{HC}$ emission increased with the increasing percentage of ethanol in blends; however, the HC emissions of ethanol-diesel blends nearly reached the level of prototype at $3200 \mathrm{r} / \mathrm{min}$.
Because the ethanol has higher latent heat of vaporization, which reduces the gas temperature and promotes the chilling of cylinder wall, the $\mathrm{HC}$ emission rises evidently with the increasing content of ethanol at low speed and load of engine. When engine speeds and loads go up, the temperature of gas and combustion chamber wall increases, which accelerates the formation of mixture gas and promotes the combustion of fuel, so the increasing blends of ethanol has litter influence on the $\mathrm{HC}$ emissions at higher engine speed and load. Thus, HC emission had slight increase and reached the level of diesel-fueled engine at some engine loads. Due to its higher latent heat of vaporization and lower cetane number, higher proportion of ethanol reduces the gas temperature and retards the ignition delay, which 


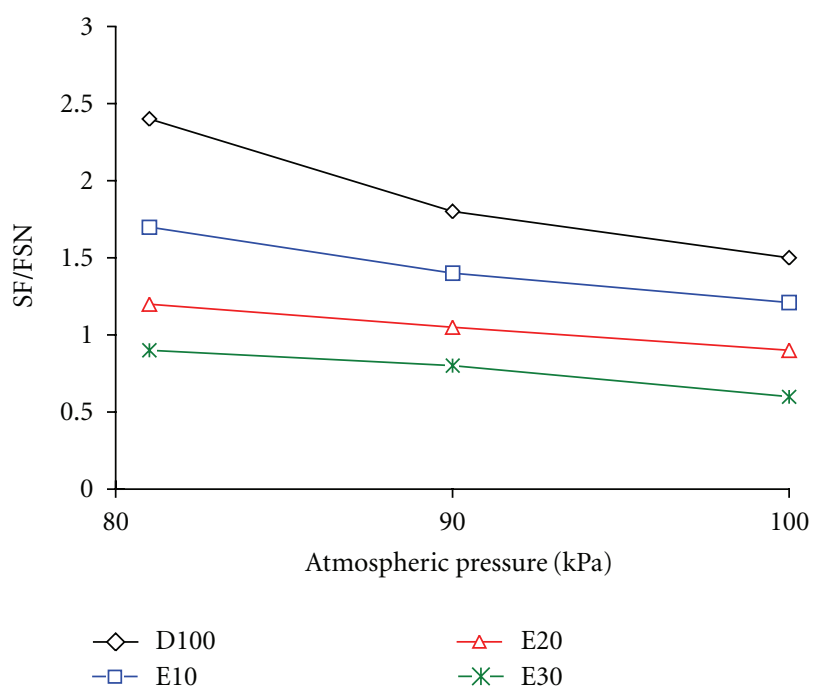

(a) $1400 \mathrm{r} / \mathrm{min} 140 \mathrm{~N} \cdot \mathrm{m}$

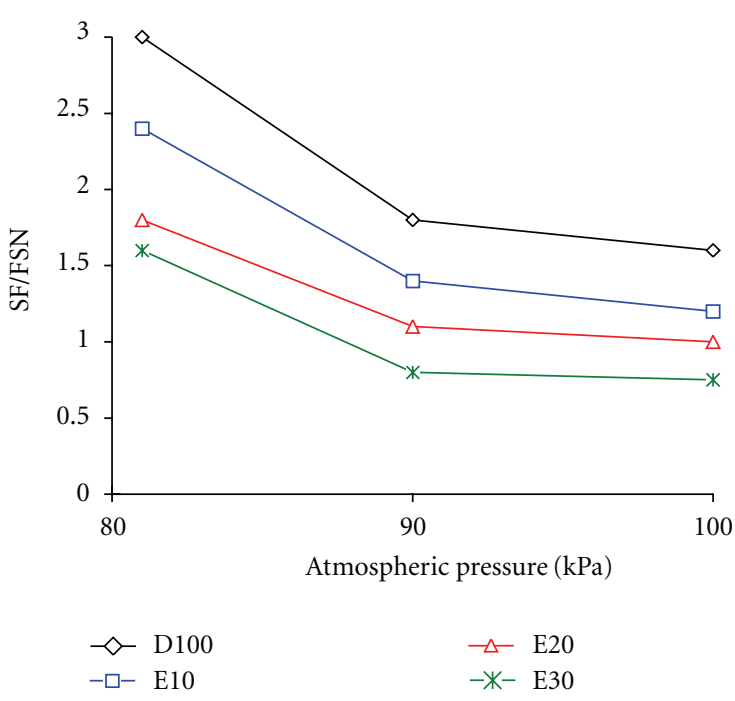

(b) $1400 \mathrm{r} / \mathrm{min} 180 \mathrm{~N} \cdot \mathrm{m}$

FIGURE 11: Comparison of smoke of different atmospheric pressure and mix proportion at speed $1400 \mathrm{r} / \mathrm{min}$.

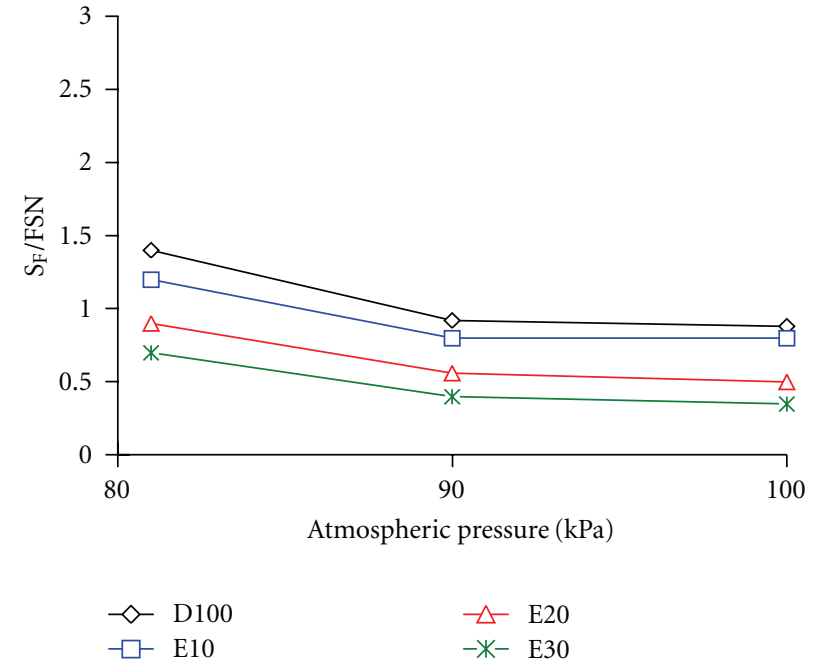

(a) $2200 \mathrm{r} / \mathrm{min} 160 \mathrm{~N} \cdot \mathrm{m}$

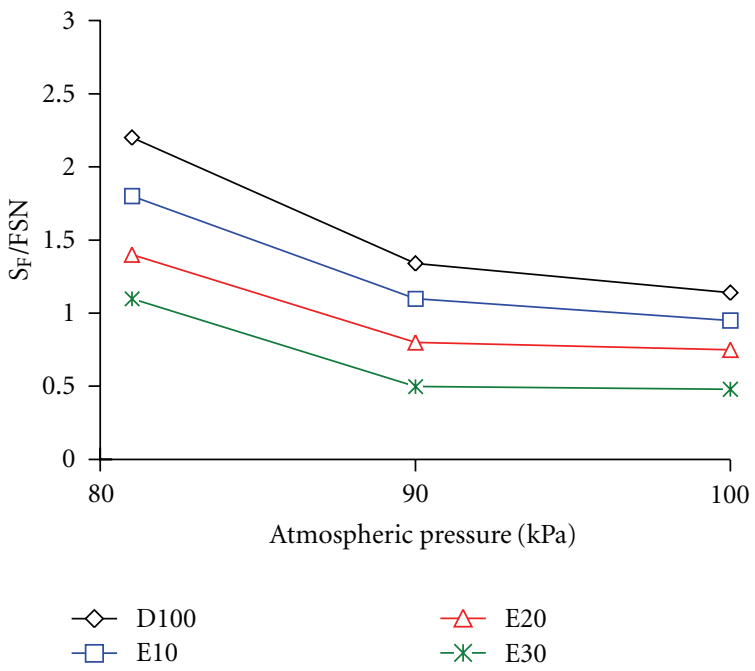

(b) $2200 \mathrm{r} / \mathrm{min} 230 \mathrm{~N} \cdot \mathrm{m}$

FIGURE 12: Comparison of smoke of different atmospheric pressure and mix proportion at speed $2200 \mathrm{r} / \mathrm{min}$.

results in the significant rise of $\mathrm{HC}$ emissions of E30 at lower speed and load. Additionally, the limited emulsifiable ability of mixture device at higher proportion of ethanol may be another reason. Based on the above analysis, it can be said that $\mathrm{HC}$ emissions of ethanol-diesel blends are depended on the engine speed, load, and the mix proportion of ethanol.

3.3. Emission Characteristics of CO. The CO emissions of ethanol-diesel blends under three atmospheric pressures were shown in Figures 5, 6, and 7. At $2200 \mathrm{r} / \mathrm{min}$ and low load $(50 \mathrm{~N} \cdot \mathrm{m}), \mathrm{E} 10, \mathrm{E} 20$, and E30 augmented the CO emissions by $20 \% \sim 250 \%, 33 \% \sim 301 \%$, and $35 \% \sim$ $210 \%$, respectively. With increasing engine speed and engine load, atmospheric pressure had litter influence on the CO emission. At low and middle loads, the higher proportion of ethanol increased the CO emission slightly. At full load, $\mathrm{CO}$ emissions of ethanol-diesel blends were lower than those of pure diesel, especially at $81 \mathrm{kPa}$. The experimental results indicated that the ethanol-diesel blends would not deteriorate the $\mathrm{CO}$ emissions except for $2200 \mathrm{r} / \mathrm{min}$ and low load.

The addition of ethanol causes the reduction of gas temperature, which restrains the oxidation of $\mathrm{CO}$, so $\mathrm{CO}$ emission goes up at low load. With the increase of engine speed and load, the increase of gas temperature, wall temperature, and oxygen content of ethanol promote the oxidation condition of $\mathrm{CO}$, which decreases the negative effect of addition of ethanol. At full load, the excess air ratio is comparatively low, so the increasing proportion of ethanol decreases the $\mathrm{CO}$ emission greatly. With the increase 


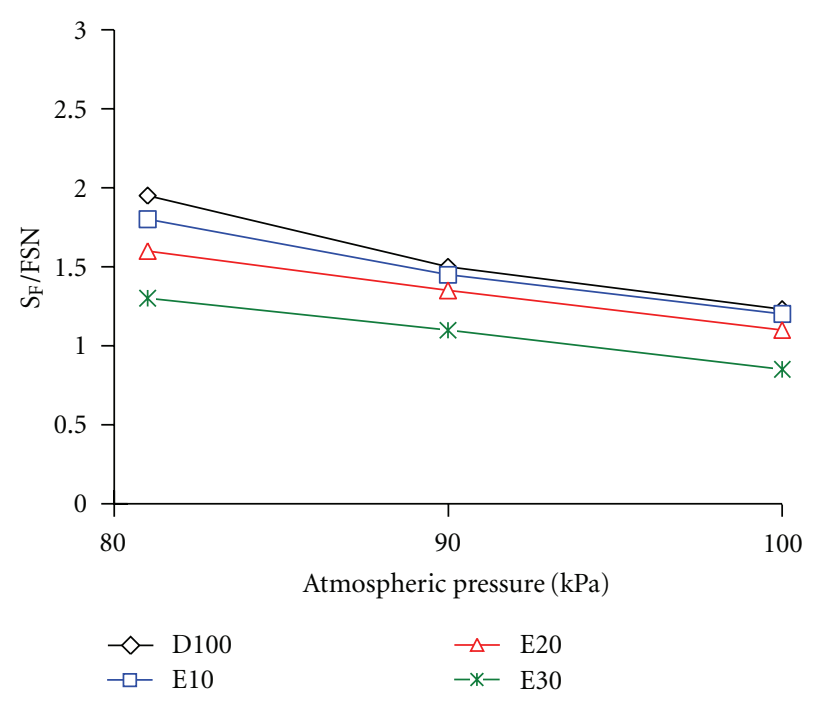

(a) $3200 \mathrm{r} / \mathrm{min} 140 \mathrm{~N} \cdot \mathrm{m}$

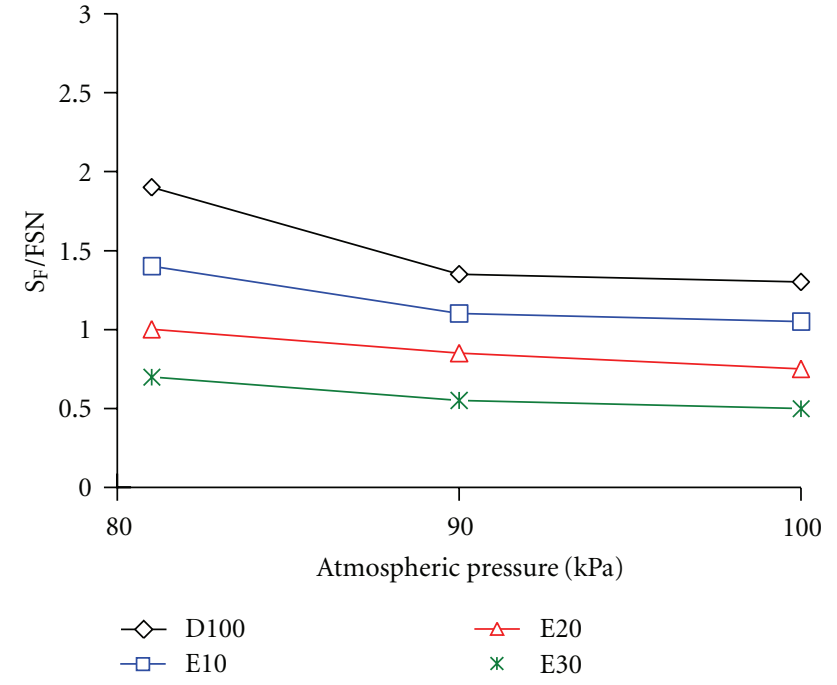

(b) $3200 \mathrm{r} / \mathrm{min} 190 \mathrm{~N} \cdot \mathrm{m}$

FIGURE 13: Comparison of smoke of different atmospheric pressure and mix proportion at speed $3200 \mathrm{r} / \mathrm{min}$.

of atmospheric pressure, the excess air ratio increases and the effect of ethanol is weakened, so the influence of atmospheric pressure on the $\mathrm{CO}$ emission is slight. Based on the above analysis, it can be said that $\mathrm{CO}$ emissions of ethanol-diesel blends are depended on the engine speed, load, and the mix proportion of ethanol.

3.4. Emission Characteristics of $N O_{x}$. Figures 8, 9, and 10 showed the NOx emissions of ethanol-diesel blends under three atmospheric pressures. At different atmospheric pressures and mix proportions, the NOx emissions showed the similar trend. The ethanol-diesel blends reduced the NOx emission at most modes. At 1400 and $2200 \mathrm{r} / \mathrm{min}$ and low load, the slight increase of NOx emission for E30 should be rendered by the bad emulsification at higher mix proportion. The increasing oxygen content can promote the formation of NOx; however, the maximum gas temperature is the most important factor of NOx formation, so the decreased gas temperature caused by higher latent heat of vaporization of ethanol can reduce the NOx emission.

3.5. Emission Characteristics of Smoke. Figures 11, 12, and 13 showed the smoke emissions of ethanol-diesel blends under three atmospheric pressures at full load. At different atmospheric pressures, the smoke emissions of ethanoldiesel blends had similar tendency as those of diesel. The smoke emissions of both blends and diesel were decreased with the increasing atmospheric pressures. Compared with pure diesel, E10, E20, and E30 reduced the smoke emissions by $18 \% \sim 26 \%, 36 \% \sim 47 \%$, and $50 \% \sim 63 \%$, respectively, at $81 \mathrm{kPa}$, by $18 \% \sim 19 \%, 40 \% \sim 38 \%$, and $63 \% \sim 59 \%$, respectively at $90 \mathrm{kPa}$, and by $17 \% \sim 19 \%, 34 \% \sim 42 \%$, and $58 \% \sim 62 \%$, respectively, at $100 \mathrm{kPa}$. It showed that higher mix proportion of ethanol resulted in lower smoke emission at the same atmospheric pressure and load. At $2200 \mathrm{r} / \mathrm{min}$ when atmospheric pressure ranged from $81 \mathrm{kPa}$ to $90 \mathrm{kPa}$ the smoke emissions of E10, E20, and E30 were reduced by $39 \%$, $43 \%$, and $55 \%$, respectively. However, when atmospheric pressure ranged from $90 \mathrm{kPa}$ to $100 \mathrm{kPa}$, the smoke emissions of E10, E20, and E30 were reduced by $14 \%, 6 \%$, and $4 \%$, respectively. It can be seen that atmospheric pressure has significant effect on the smoke emission when atmospheric pressure is lower than $90 \mathrm{kPa}$. The influence is weakened when it is above $90 \mathrm{kPa}$.

The oxygen atom is usually connected to carbon atom in oxygenated fuel, and it is difficult to break the bond, which restrains the formation of aromatic hydrocarbon and black carbon, so the oxygen content of ethanol can provide oxygen atom in the fuel-rich region and inhibit the formation of smoke, especially at heavy load. At heavy load, the excess air ratio is low, so the oxygen content of ethanol can show greatly positive effect on the smoke emission. On the other hand, ethanol has lower carbon and sulfur percentage, little aromatic hydrocarbon, and lower surface tension and boiling point, which can promote the spray and combustion characteristics of ethanol-diesel blends and restrain the smoke emission.

\section{Conclusions}

(1) The power performance of engine fueled with ethanol-diesel blends can meet the demand of prototype after adjusting the fuel delivery. With increasing atmospheric pressure, the equivalent specific fuel consumption of both mixtures and pure diesel showed the same trend of decrease. When the atmospheric pressure is lower than $90 \mathrm{kPa}$, the equivalent specific fuel consumption is significantly improved with the rise of atmospheric pressure; and the improvement is weakened when atmospheric pressure is above $90 \mathrm{kPa}$. 
(2) At $81 \mathrm{kPa}$, the $\mathrm{HC}$ emission rises greatly with the decrease of speed and load and the increase of ethanol content, especially at low load. The increasing mix proportion of ethanol has little influence on the HC emission when atmospheric pressure ranges from $90 \mathrm{kPa}$ to $100 \mathrm{kPa}$.

(3) At $81 \mathrm{kPa}$, the $\mathrm{CO}$ emission rises greatly with the decrease of speed and the increase of ethanol content, especially at low load. At $90 \mathrm{kPa}$ and $100 \mathrm{kPa}$, the $\mathrm{CO}$ emission increases slightly with the increasing mix proportion at low and middle load, while the $\mathrm{CO}$ emission is reduced at heavy load.

(4) Atmospheric pressure and mix proportion have no obvious influence on NOx emission. Under most working conditions, NOx emission of ethanol-diesel blends has a slight drop compared to that of diesel.

(5) The smoke emission drops obviously with increasing atmospheric pressure. Furthermore, the higher mix proportion of ethanol results in the lower smoke emission. Atmospheric pressure has significant effect on the smoke emission when it is lower than $90 \mathrm{kPa}$. The influence is weakened when it is above $90 \mathrm{kPa}$.

\section{Acknowledgment}

This work was supported by the National Natural Science Foundation of China (Grant no. 50766001).

\section{References}

[1] C. D. Rakopoulos, K. A. Antonopoulos, D. C. Rakopoulos, and D. T. Hountalas, "Multi-zone modeling of combustion and emissions formation in DI diesel engine operating on ethanoldiesel fuel blends," Energy Conversion and Management, vol. 49, no. 4, pp. 625-643, 2008.

[2] A. C. Hansen, Q. Zhang, and P. W. L. Lyne, "Ethanol-diesel fuel blends-a review," Bioresource Technology, vol. 96, no. 3, pp. 277-285, 2005.

[3] L. Z. Shen, W. S. Yan, Y. H. Bi, and J. L. Lei, "Performance comparison of ethanol/diesel blends mixed in different methods of diesel engine," Journal of Combustion Science and Technology, vol. 13, no. 5, pp. 389-392, 2007.

[4] M. Abu-Qudais, O. Haddad, and M. Qudaisat, "Effect of alcohol fumigation on diesel engine performance and emissions," Energy Conversion and Management, vol. 41, no. 4, pp. 389$399,2000$.

[5] E. A. Ajav, B. Singh, and T. K. Bhattacharya, "Performance of a stationary diesel engine using vapourized ethanol as supplementary fuel," Biomass and Bioenergy, vol. 15, no. 6, pp. 493-502, 1998.

[6] P. Satgé de Caro, Z. Mouloungui, G. Vaitilingom, and J. C. Berge, "Interest of combining an additive with diesel-ethanol blends for use in diesel engines," Fuel, vol. 80, no. 4, pp. 565574, 2001.

[7] N. Noguchi, H. Terao, and C. Sakata, "Performance improvement by control of flow rates and diesel injection timing on dual-fuel engine with ethanol," Bioresource Technology, vol. 56, no. 1, pp. 35-39, 1996.
[8] H. Chen, S. J. Shuai, and J. X. Wang, "Study on combustion characteristics and PM emission of diesel engines using esterethanol-diesel blended fuels," Proceedings of the Combustion Institute, vol. 31, pp. 2981-2989, 2007.

[9] E. W. De Menezes, R. da Silva, R. Cataluña, and R. J. C. Ortega, "Effect of ethers and ether/ethanol additives on the physicochemical properties of diesel fuel and on engine tests," Fuel, vol. 85, no. 5-6, pp. 815-822, 2006.

[10] S. G. Poulopoulos, D. P. Samaras, and C. J. Philippopoulos, "Regulated and unregulated emissions from an internal combustion engine operating on ethanol-containing fuels," Atmospheric Environment, vol. 35, no. 26, pp. 4399-4406, 2001.

[11] X. Lu, J. Yang, W. Zhang, and H. Zhen, "Effect of cetane number improver on heat release rate and emissions of high speed diesel engine fueled with ethanol-diesel blend fuel," Fuel, vol. 83, no. 14-15, pp. 2013-2020, 2004.

[12] D. Li, H. Zhen, X. Lu, W. Zhang, and J. Yang, "Physicochemical properties of ethanol-diesel blend fuel and its effect on performance and emissions of diesel engines," Renewable Energy, vol. 30, no. 6, pp. 967-976, 2005.

[13] B. Q. He, S. J. Shuai, J. X. Wang, and H. He, "The effect of ethanol blended diesel fuels on emissions from a diesel engine," Atmospheric Environment, vol. 37, no. 35, pp. 49654971, 2003.

[14] D. C. Rakopoulos, C. D. Rakopoulos, E. G. Giakoumis, R. G. Papagiannakis, and D. C. Kyritsis, "Experimental-stochastic investigation of the combustion cyclic variability in HSDI diesel engine using ethanol-diesel fuel blends," Fuel, vol. 87, no. 8-9, pp. 1478-1491, 2008.

[15] C. D. Rakopoulos, K. A. Antonopoulos, and D. C. Rakopoulos, "Experimental heat release analysis and emissions of a HSDI diesel engine fueled with ethanol-diesel fuel blends," Energy, vol. 32, no. 10, pp. 1791-1808, 2007.

[16] D. C. Rakopoulos, C. D. Rakopoulos, E. C. Kakaras, and E. G. Giakoumis, "Effects of ethanol-diesel fuel blends on the performance and exhaust emissions of heavy duty DI diesel engine," Energy Conversion and Management, vol. 49, no. 11, pp. 3155-3162, 2008.

[17] N. Noguchi, H. Terao, and C. Sakata, "Performance improvement by control of flow rates and diesel injection timing on dual-fuel engine with ethanol," Bioresource Technology, vol. 56, no. 1, pp. 35-39, 1996.

[18] C. Sayin and M. Canakci, "Effects of injection timing on the engine performance and exhaust emissions of a dual-fuel diesel engine," Energy Conversion and Management, vol. 50, no. 1, pp. 203-213, 2009.

[19] E. A. Ajav, B. Singh, and T. K. Bhattacharya, "Experimental study of some performance parameters of a constant speed stationary diesel engine using ethanol-diesel blends as fuel," Biomass and Bioenergy, vol. 17, no. 4, pp. 357-365, 1999.

[20] H. Chen, J. Wang, S. Shuai, and W. Chen, "Study of oxygenated biomass fuel blends on a diesel engine," Fuel, vol. 87, no. 1516, pp. 3462-3468, 2008.

[21] X. Shi, Y. Yu, H. He, S. Shuai, J. Wang, and R. Li, "Emission characteristics using methyl soyate-ethanol-diesel fuel blends on a diesel engine," Fuel, vol. 84, no. 12-13, pp. 1543-1549, 2005.

[22] M. Lapuerta, O. Armas, and J. M. Herreros, "Emissions from a diesel-bioethanol blend in an automotive diesel engine," Fuel, vol. 87, no. 1, pp. 25-31, 2008.

[23] C. S. Cheung, Y. Di, and Z. Huang, "Experimental investigation of regulated and unregulated emissions from a diesel engine fueled with ultralow-sulfur diesel fuel blended with 
ethanol and dodecanol," Atmospheric Environment, vol. 42, no. 39, pp. 8843-8851, 2008.

[24] C. L. Song, Y. C. Zhou, R. J. Huang et al., "Influence of ethanol-diesel blended fuels on diesel exhaust emissions and mutagenic and genotoxic activities of particulate extracts," Journal of Hazardous Materials, vol. 149, no. 2, pp. 355-363, 2007.

[25] L. Shen, Y. Shen, and W. Yan, "Combustion process of diesel engines at regions with different altitudes," SAE Paper, 950857, 1995.

[26] L. Shen, Y. Shen, and W. Yan, "Dimensionless analysis of the properties of diesel engines at different pressures," SAE Paper, 952064, 1995.

[27] P. Benjumea, J. Agudelo, and A. Agudelo, "Effect of altitude and palm oil biodiesel fuelling on the performance and combustion characteristics of a HSDI diesel engine," Fuel, vol. 88, no. 4, pp. 725-731, 2009. 

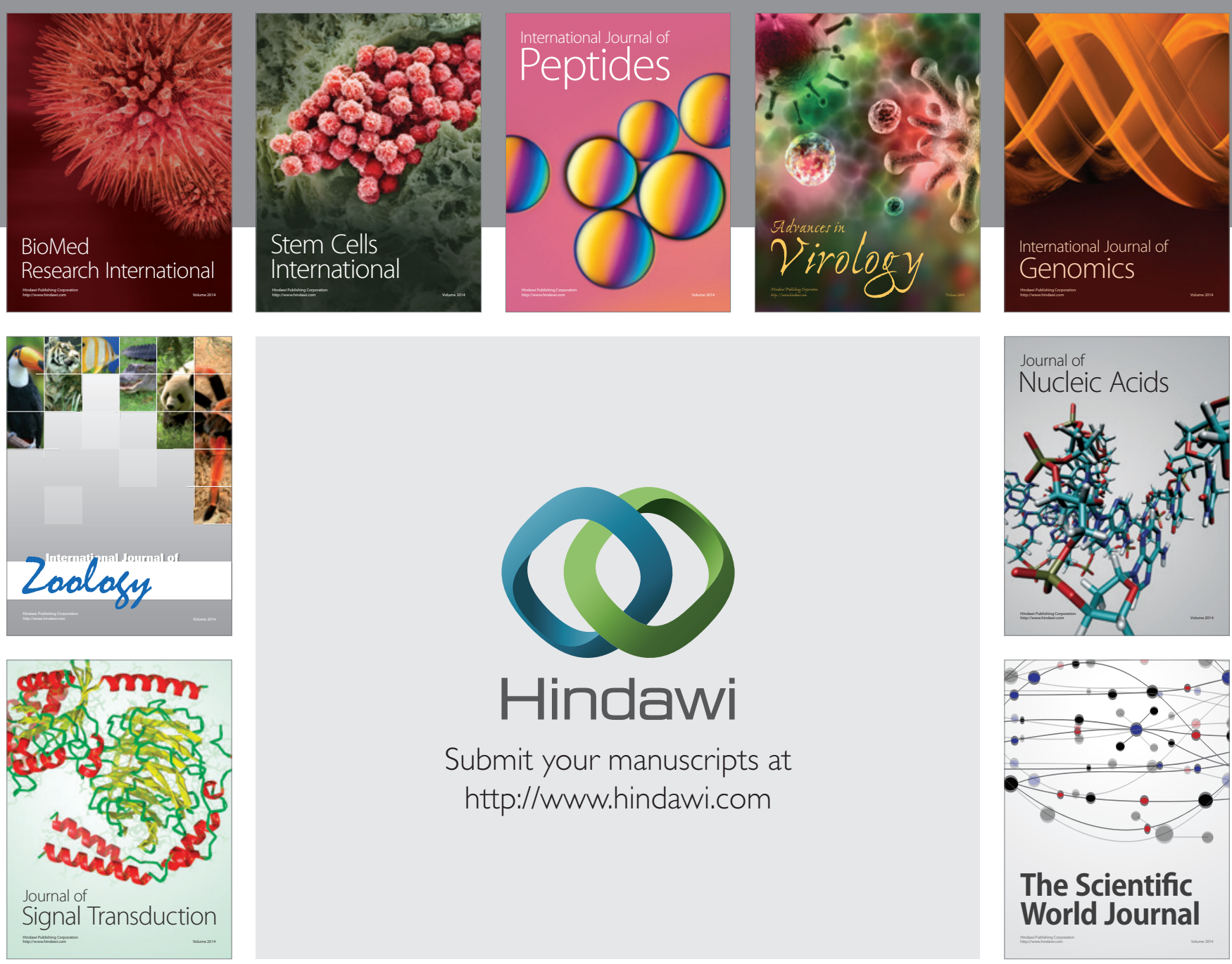

Submit your manuscripts at

http://www.hindawi.com
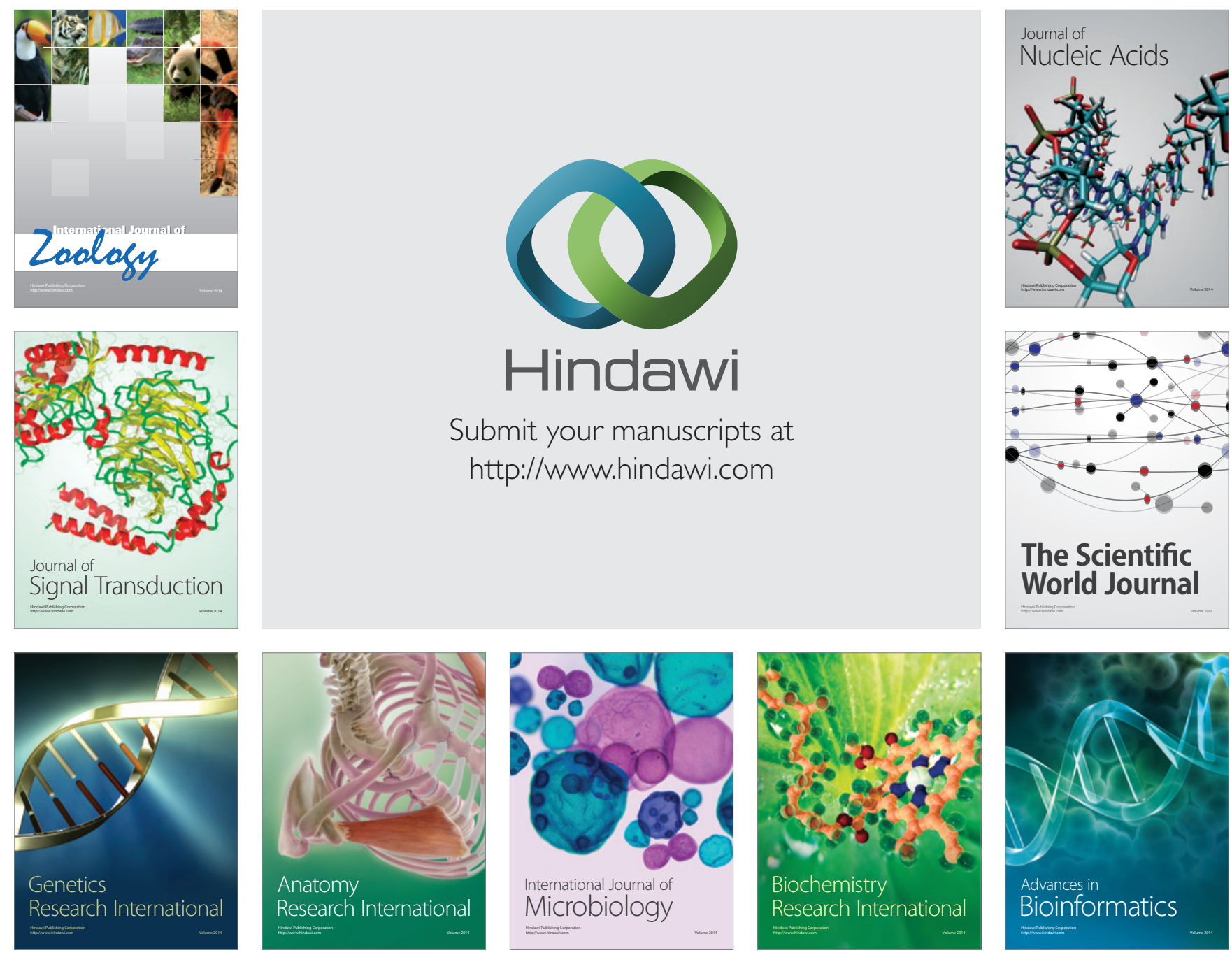

The Scientific World Journal
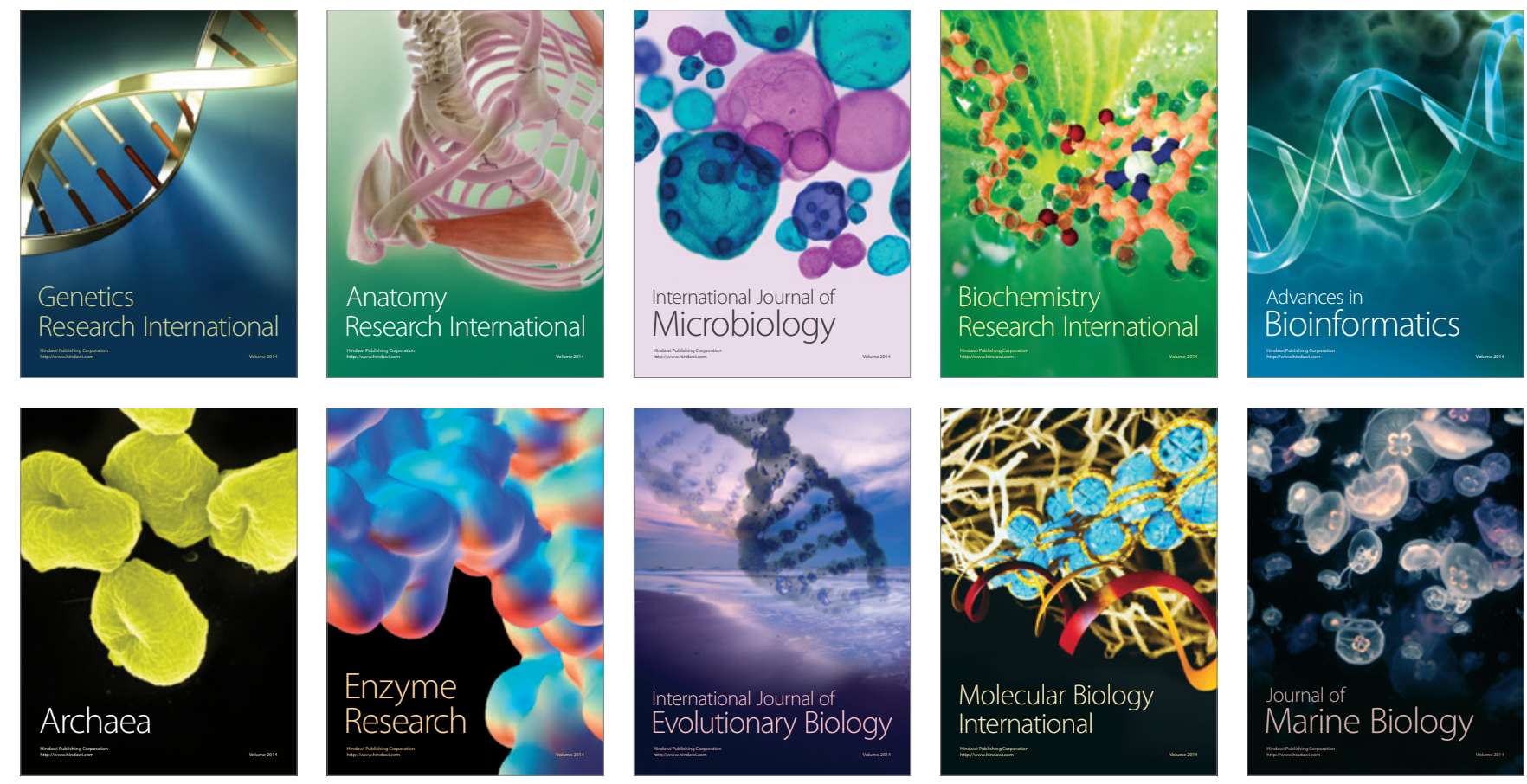